\title{
Sodium Chloride Aggravates Arthritis via Th17 Polarization
}

\author{
Seung Min Jung ${ }^{1 *}$, Youngkyun Kim²*, Juryun Kim², Hyerin Jung ${ }^{2}$, Hyoju Yi², Yeri Alice Rim², \\ Narae Park ${ }^{2}$, Seung-Ki Kwok², Sung-Hwan Park ${ }^{2}$, and Ji Hyeon Ju² \\ ${ }^{1}$ Division of Rheumatology, Department of Internal Medicine, Yonsei University College of Medicine, Seoul; \\ ${ }^{2}$ Division of Rheumatology, Department of Internal Medicine, Seoul St. Mary's Hospital, College of Medicine, The Catholic University of Korea, \\ Seoul, Korea.
}

Purpose: Sodium chloride ( $\mathrm{NaCl}$ ) has been proposed as a driving factor in autoimmune diseases through the induction of pathogenic $\mathrm{CD}^{+} \mathrm{T}$ helper cells that produce interleukin- 17 (Th17 cells). This study investigated the effects of NaCl on inflammatory arthritis in mice and humans.

Materials and Methods: Collagen-induced arthritis (CIA) mice were fed a normal or high-salt diet ad libitum, and clinical and histologic features of arthritis were evaluated. The proportion of Th17 cells in the spleens of CIA mice fed a normal or high-salt diet was evaluated by flow cytometry, and the expression of IL-17 in joints and intestines was determined by immunohistochemical staining. We also analyzed the effect of $\mathrm{NaCl}$ on $\mathrm{Th} 17$ differentiation from peripheral blood monocytes of patients with rheumatoid arthritis (RA) and osteoarthritis (OA) and evaluated the contents of sodium and IL-17 in the synovial fluid of RA and OA patients.

Results: $\mathrm{NaCl}$ increased murine and human Th17 cell differentiation in a dose-dependent manner. Clinical and histological arthritis was more severe in the high-salt-fed CIA mice, compared to control CIA mice. The proportion of Th17 cells among splenocytes was higher in CIA mice fed a high-salt diet. Expression of synovial and intestinal IL-17 was also higher in high-salt-fed CIA mice. Comparison of synovial fluid between RA patients and OA patients revealed that $\mathrm{Na}^{+}$and IL-17 were more abundant in RA synovial fluid.

Conclusion: This study suggests that $\mathrm{NaCl}$ can aggravate arthritis by affecting Th17 differentiation. Accordingly, limiting salt intake may be helpful for treating inflammatory arthritis, such as RA.

Key Words: Rheumatoid arthritis, salt, sodium chloride, Th17 cells, collagen-induced arthritis

\section{INTRODUCTION}

Rheumatoid arthritis (RA) is a systemic autoimmune disease characterized by inflammatory polyarthritis that leads joint

Received: June 27, 2018 Revised: October 31, 2018

Accepted: November 7, 2018

Corresponding author: Ji Hyeon Ju, MD, PhD, Division of Rheumatology, Department of Internal Medicine, Seoul St. Mary's Hospital, College of Medicine, The Catholic University of Korea, 222 Banpo-daero, Seocho-gu, Seoul 06591, Korea. Tel: 82-2-2258-6893, Fax: 82-2-3476-2274, E-mail: juji@catholic.ac.kr

This study was presented at the 34 th Korean College of Rheumatology Annual Scientific Meeting (2014. 5. 16).

*Seung Min Jung and Youngkyun Kim contributed equally to this work.

-The authors have no potential conflicts of interest to disclose.

(C) Copyright: Yonsei University College of Medicine 2019

This is an Open Access article distributed under the terms of the Creative Commons Attribution Non-Commercial License (https://creativecommons.org/licenses/ by-nc/4.0) which permits unrestricted non-commercial use, distribution, and reproduction in any medium, provided the original work is properly cited. destruction and deformity. Although the pathogenesis of RA has not yet been elucidated, it is well known that interleukin (IL)-17-producing $\mathrm{CD}^{+} \mathrm{T}$ helper (Th17) cells play an important role in the development and progression of RA. ${ }^{1,2}$ IL-17 aggravates synovial inflammation and bone destruction by promoting the production of pro-inflammatory cytokines, such as IL-6, IL-1 $\beta$, tumour necrosis factor- $\alpha$ (TNF- $\alpha)$, and matrix metalloproteinases. Moreover, increased expression of receptor activator of nuclear factor- $\mathrm{\kappa B}$ ligand (RANKL) by IL17 activates osteoclasts and subsequently causes bone loss. Because Th17 cells play a major role in the pathogenesis of inflammatory arthritis, efforts have been made to identify potential contributors that promote Th17 differentiation.

RA is caused by interactions among environmental factors and genetic predisposition. Because genetic susceptibility is difficult to control, efforts to identify environmental factors that promote or inhibit the development of RA are ongoing. Epide- 
miological studies have suggested associations between RA and environmental triggers, such as smoking and gingivitis, although the pathologic mechanisms are still unclear. Clinical trials have also been conducted on diets to examine whether dietary intake attenuates the proinflammatory response of RA..$^{3-6}$ However, there is a limited amount of data on the modifiable risk factors for RA. ${ }^{7}$

Two recent studies reported that pathogenic Th17 cells can be inducted by sodium chloride $(\mathrm{NaCl})$, suggesting that salt may be a risk factor for autoimmune diseases ${ }^{8,9}$ Increased $\mathrm{NaCl}$ concentration enhances differentiation into Th17 cells via the $\mathrm{p} 38 /$ mitogen-activated protein kinase signaling pathway, which involves nuclear factor of activated T cells 5 (NFAT5) and serum- and glucocorticoid-inducible kinase 1 (SGK1). NFAT5 and SGK1 were originally identified as regulators that respond to cell volume and osmotic pressure. However, the activation of NFAT5 and SGK1 is also affected by inflammatory cytokines. SGK1 is expressed ubiquitously and is induced by IL-6, which is an important pro-inflammatory cytokine. ${ }^{10}$ SGK1 increases the expression of IL-23 receptor, and this increase in IL-23 receptor contributes to the stable action of IL-23 on Th17 phenotype. ${ }^{9}$ NFAT5 is highly expressed in RA synovium, and is induced by TNF- $\alpha$ and IL- $\beta .^{11,12}$ In the pathogenesis of RA, NFAT5 is associated with cell survival, migration and angiogenesis. ${ }^{12}$

Based on recent studies of the proinflammatory role of salt in autoimmune diseases, we investigated the effect of a highsalt diet on inflammatory arthritis in mice with collagen-induced arthritis (CIA). Clinical and histological arthritis was evaluated in CIA mice fed a high-salt diet or normal diet, and the distribution of IL-17-producing cells in the tissues was examined in both groups. In addition, we assessed the effect of $\mathrm{NaCl}$ on Th17 differentiation in patients with RA and osteoarthritis (OA).

\section{MATERIALS AND METHODS}

\section{Induction of collagen-induced arthritis and feeding of the high-salt diet}

DBA/1J mice at seven weeks of age (purchased from OrientBio, Seongnam, Republic of Korea) were injected intradermally on the back with $100 \mu \mathrm{g}$ of CII in complete Freund's adjuvant (Chondrex, Redmond, WA, USA). A second immunization with $100 \mu \mathrm{g}$ of CII in incomplete Freund's adjuvant (Chondrex) was performed 3 weeks after the first immunization. To evaluate the effect of $\mathrm{NaCl}$ on inflammatory arthritis, CIA mice were fed a normal or a high-salt diet ad libitum ( $\mathrm{n}=10$ in each group). CIA mice in the high-salt group received tap water that contained $1 \% \mathrm{NaCl}$ before the first immunization and chow that contained $4 \% \mathrm{NaCl}$ at the first immunization. Clinical arthritis score was evaluated by two independent examiners twice a week until sacrifice on day 56. Each paw was scored on a grad- ed scale from 0 to 4 as described previously. ${ }^{13}$ A representative arthritis score was calculated by summing the scores for the four paws. All the experimental procedures were reviewed and approved by the Animal Research Ethics Committee at the Catholic University of Korea (2014-0088-03).

Synovial fluid and serum from patients with RA and OA Patients who satisfied the relevant classification criteria for $\mathrm{RA}^{14,15}$ or $\mathrm{OA}^{16}$ were recruited from the outpatient clinic in the Department of Rheumatology, Seoul St. Mary's Hospital, Seoul, Korea. An informed consent was obtained from all patients. Synovial fluid was obtained from arthrocentesis of swollen knee joints, which was performed for therapeutic purposes $(\mathrm{n}=17$ for $\mathrm{RA}$, and $\mathrm{n}=16$ for $\mathrm{OA}$ ). The $\mathrm{Na}^{+}$concentration and leukocyte counts in the synovial fluid were measured using routine laboratory tests. Synovial IL-17 concentration was determined using a sandwich enzyme-linked immunosorbent assay $(R \& D$ Systems, Minneapolis, MN, USA) according to the manufacturer's instructions. Peripheral blood mononuclear cells (PBMCs) isolated from the heparinized blood of RA patients $(\mathrm{n}=3)$ and OA patients $(\mathrm{n}=2)$ were differentiated into Th17 cells under high $\mathrm{NaCl}$ conditions. The study was approved by the Institutional Review Board of Seoul St. Mary's Hospital (KC13TISI0240).

\section{Murine Th17 differentiation}

$\mathrm{CD}^{+} \mathrm{T}$ cells were isolated from spleens of control mice or CIA mice by positive selection using a magnetic sorter with microbeads (Miltenyi Biotec Inc., Bergisch Gladbach, Germany). Murine $\mathrm{CT}^{+} \mathrm{T}$ cells were cultured in RPMI-1640 (10\% fetal bovine serum; Gibco, Carlsbad, CA, USA) and were stimulated with $2 \mu \mathrm{g} / \mathrm{mL}$ of plate-bound anti-CD3 (BD Biosciences, San Jose, CA, USA) for 3 days. Th17 cells were cultured with 5 $\mu \mathrm{g} / \mathrm{mL}$ of anti-CD28 (BD Biosciences), $10 \mu \mathrm{g} / \mathrm{mL}$ of anti-IL-4, $10 \mu \mathrm{g} / \mathrm{mL}$ of anti-interferon $\gamma$ (IFN $\gamma$ ), $50 \mathrm{ng} / \mathrm{mL}$ of IL-6, and 1 $\mathrm{ng} / \mathrm{mL}$ of transforming growth factor $\beta$ (TGF- $\beta$ ) (all from R\&D Systems). $\mathrm{NaCl}$ was added at concentrations of $10,20,40,60$, or $80 \mathrm{mM}$. Because the concentration of $\mathrm{NaCl}$ in RPMI-1640 media is $104.4 \mathrm{mM}$, the final $\mathrm{NaCl}$ concentrations were 114.4, 124.4, 144.4, 164.4, or $184.4 \mathrm{mM}$ during Th17 differentiation.

\section{Human Th17 differentiation}

PBMCs were collected by centrifugation of human blood at $2000 \mathrm{rpm}$ at $20^{\circ} \mathrm{C}$ for $30 \mathrm{~min}$ with Ficoll-Paque PLUS (GE Healthcare, Little Chalfont, UK). Naïve $\mathrm{CD}^{+}{ }^{+} \mathrm{T}$ cells were isolated from PBMCs using a Naïve $\mathrm{CD} 4^{+} \mathrm{T}$ Cell Isolation Kit II (Miltenyi Biotec Inc.). CD4 ${ }^{+} \mathrm{T}$ cells were cultured in 96-well plates coated with $10 \mu \mathrm{g} / \mathrm{mL}$ anti-human CD3 (BD Biosciences). To induce Th17 differentiation, naïve $\mathrm{CD}^{+}{ }^{+} \mathrm{T}$ cells were cultured with $1 \mu \mathrm{g} / \mathrm{mL}$ anti-CD28 (BD Biosciences), $25 \mathrm{ng} / \mathrm{mL}$ IL-23, 5 ng/mL TGF- $\beta, 12.5$ ng/mL IL-1 $\beta$, and 25 ng/mL IL-6 (all cytokines from R\&D Systems) for 5 days. 


\section{Flow cytometry}

Murine splenocytes were incubated with allophycocyanin (APC)-conjugated anti-CD4 antibodies (BD Biosciences) and then permeabilized using a Foxp3 Staining Buffer Set (eBioscience, San Diego, CA, USA). To identify Th17 cells, murine $\mathrm{CD}^{+} \mathrm{T}$ cells were stained with anti-ROR $\gamma \mathrm{t}$ antibodies conjugated with phycoerythrin or anti-IL-17 antibodies conjugated with fluorescein isothiocyanate (both from eBioscience). For detection of IL-17, cells were incubated with $5 \mathrm{ng} / \mathrm{mL}$ of phorbol-12-myristate-13-acetate (PMA), $500 \mathrm{ng} / \mathrm{mL}$ ionomycin, and $1 \mu \mathrm{L} / \mathrm{mL}$ of GolgiPlug (BD Biosciences) for $4 \mathrm{~h}$ prior to staining with anti-IL-17 antibodies.

Human Th17 cells were identified based on co-expression of ROR $\gamma \mathrm{t}$, and IL-17. PBMCs were incubated with $50 \mathrm{ng} / \mathrm{mL}$ of PMA, $250 \mathrm{ng} / \mathrm{mL}$ of ionomycin, and $1 \mu \mathrm{L} / \mathrm{mL}$ of GolgiPlug for $4 \mathrm{~h}$. After incubation with anti-CD4 eFluor 450 (eBioscience), cells were permeabilized using a Foxp3 Transcription Factor Staining Buffer Set (eBioscience). ROR $\gamma$ t and IL-17 expression was detected by staining with anti-ROR $\gamma \mathrm{t}$ antibodies conjugated with phycoerythrin and anti-IL-17A antibodies conjugated with APC (both from eBioscience). After staining with antibodies, the cells were assessed on an LSRFortessa cell analyzer (BD Biosciences). The acquired data were analyzed using FlowJo 7.6.5 software (TreeStar Inc., Ashland, OR, USA).

\section{Histological assessment of synovial tissues}

The joint tissues from the hind paws were fixed in $4 \%$ paraformaldehyde and decalcified in 10\% EDTA bone decalcifier prior to embedding in paraffin. Sections at a 5 - $\mu$ m thickness were stained with Hematoxylin and Eosin, Safranin O Fast Green, and Toluidine Blue. The severity of synovial inflammation and joint destruction was measured by three individual researchers in a blinded manner, as described previously. ${ }^{17}$ Arthritis scores for inflammation and destruction were determined by the severity of cellular infiltration and hyperplasia and by pannus formation and cartilage erosion, respectively.

\section{Immunofluorescence staining}

The tarsal joint, small intestine, and large intestine of the mice were fixed, transferred into $30 \%$ sucrose, and then incubated overnight at $4^{\circ} \mathrm{C}$. Endogenous peroxidase activity was blocked with $3 \% \mathrm{H}_{2} \mathrm{O}_{2}$ prepared in phosphate buffered saline (PBS). Nonspecific binding sites were blocked with $10 \%$ normal goat serum (Vector Lab, Burlingame, CA, USA) containing 1\% PBA (phosphate buffered saline containing $1 \%$ bovine serum albu$\mathrm{min}$ ). The tissue samples were incubated with rabbit polyclonal anti-IL-17 antibodies (Abcam, Cambridge, UK) diluted in 5\% normal goat serum containing $1 \%$ PBA (1:500) overnight at $4{ }^{\circ} \mathrm{C}$. The sections were then incubated with Alexa Fluor 594 goat anti-rabbit IgG $(\mathrm{H}+\mathrm{L})$ antibodies (Thermo Fisher Scientific, Waltham, MA, USA) diluted in PBS (1:200) at room temperature for $40 \mathrm{~min}$. Nucleus staining was performed using 4'6-diamidino-2-phenylindole (DAPI, Roche, Basel, Swit- zerland). To evaluate the abundance of IL- $17^{+}$cells in the tissue samples, IL- $17^{+}$cells were manually counted by two independent investigators under a microscope at low power ( $\times 100$ or $\times 200$ magnification) .

\section{Statistical analysis}

Experimental data are presented as means and standard errors. Statistical significance was determined using the MannWhitney U test. All $p$ values $<0.05$ were considered significant. All data were analyzed using SAS software (v. 9.1; SAS Institute, Cary, NC, USA) and GraphPad Prism software (v. 5.01; GraphPad, San Diego, CA, USA).

\section{RESULTS}

\section{$\mathrm{NaCl}$ increases murine Th17 differentiation}

To induce $\mathrm{Th} 17$ differentiation, $\mathrm{CD} 4^{+} \mathrm{T}$ cells isolated from $\mathrm{mu}$ rine splenocytes were stimulated with anti-CD3 and antiCD28 antibodies, IL-6, and TGF- $\beta$ and were inhibited with anti-IL- 4 and anti-IFN $\gamma$ antibodies for 3 days (Fig. 1A). Murine $\mathrm{CD}^{+} \mathrm{T}$ cells were cultured under Th17-polarizing condition in the presence of various $\mathrm{NaCl}$ concentrations. $\mathrm{NaCl}$ up to concentration of $40 \mathrm{mM}$ dose-dependently increased the proportion of $\mathrm{CD} 4^{+} \mathrm{ROR} \gamma \mathrm{t}^{+}$cells (Fig. 1B). However, we observed cellular apoptosis and an abrupt decrease in the number of $\mathrm{CD} 4^{+} \mathrm{ROR} \gamma \mathrm{t}^{+}$cells at a concentration of $80 \mathrm{mM} \mathrm{NaCl}$.

\section{High-salt diet aggravates inflammatory arthritis in mice}

The high-salt diet was composed of $4 \% \mathrm{NaCl}$-containing chow and $1 \% \mathrm{NaCl}$-containing water. $\mathrm{NaCl}$-enriched meals were administered to CIA mice since first immunization with CII, and the $\mathrm{NaCl}$ challenge was continued for the entire experimental period until day 58 (Fig. 2A). A high-salt diet exacerbates the clinical and histological features of inflammatory arthritis in CIA mice. Arthritis scores were consistently higher in the CIA mice fed a high-salt diet than in the CIA mice fed a normal diet (Fig. 2B). Joint swelling of hind paws was more severe in highsalt-fed CIA mice than in control CIA mice (Fig. 2C). Histological assessment revealed massive infiltration of inflammatory cells, cartilage destruction, and bone erosion in high-salt-fed CIA mice. Evaluation of articular cartilage by Safranin-O and Toluidine Blue staining showed more prominent thinning and erosion of cartilage in high-salt-fed CIA mice (Fig. 2D). The histological score to quantify synovial inflammation and joint destruction was significantly higher in high-salt-fed CIA mice, compared with control CIA mice (Fig. 2E).

\section{NaCl-rich environment primes Th17 polarization in mice}

Splenocytes were extracted from both high-salt-fed CIA and control CIA mice. Ex vivo analysis of splenocytes showed a 

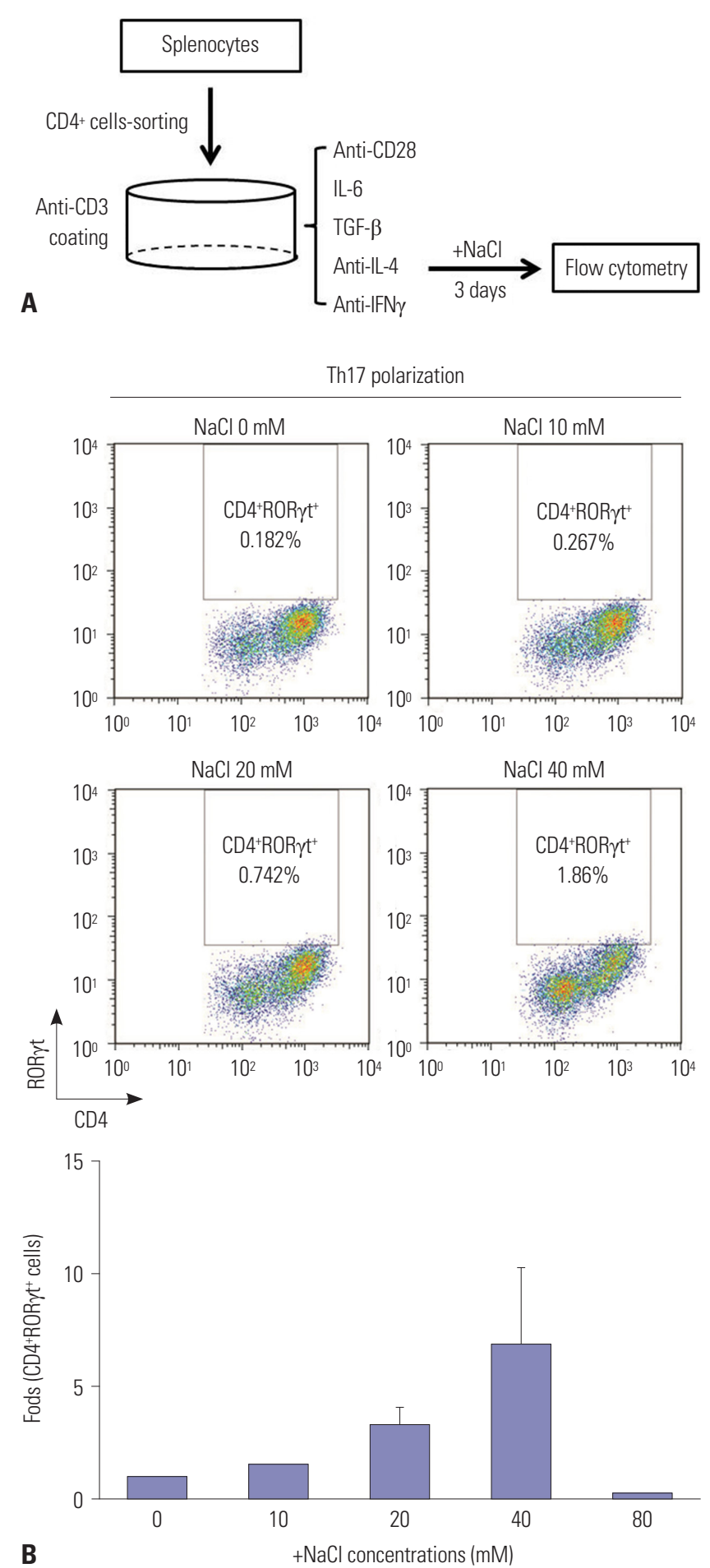

Fig. 1. NaCl induces Th17 differentiation in vitro. (A) A schematic diagram for evaluating the effect of salt on Th17 differentiation. Naiive CD4 ${ }^{+} \mathrm{T}$ cells isolated from the spleens of DBA/1J mice were cultured under Th17-polarizing conditions in the absence or presence of $\mathrm{NaCl}$ at different concentrations $(10,20,40$, and $80 \mathrm{mM})$ for 3 days. (B) Representative flow cytometry plots of differentiated Th17 cells at different $\mathrm{NaCl}$ concentrations. The displayed numbers are the percentage of $\mathrm{CD}^{+} \mathrm{ROR} \gamma \mathrm{t}^{+}$-labeled cells. Fold increases were calculated as the percentage of $\mathrm{CD} 4^{+} \mathrm{ROR} \gamma \mathrm{t}^{+} \mathrm{Th} 17$ cells relative to the percentage in the $\mathrm{NaCl}$-deficient condition. Data are representative of three independent experiments and are expressed as mean \pm SEM. higher proportion of Th17 cells expressing CD4 and ROR $\gamma \mathrm{t}$ in high-salt-fed CIA mice, compared with control CIA mice (fold change 1.15 vs. 1.0, $p<0.05$ ) (Fig. 3A). To evaluate the priming effect of a high-salt diet on Th17 differentiation, $\mathrm{CD}^{+} \mathrm{T}$ cells isolated from CIA mice in each group were cultured under Th17-polarizing condition. $\mathrm{CD} 4^{+} \mathrm{T}$ cells from high-salt-fed CIA mice were more likely to express IL-17A than those from control CIA mice (fold change 1.8 vs. 1.0, $p<0.05$ ) (Fig. 3B).

\section{High-salt diet increases IL-17-producing cells in synovial and intestinal tissue in CIA mice}

Because high $\mathrm{NaCl}$ concentrations enhanced Th17 differentiation in vitro, we performed an in vivo investigation to examine the effects of a high-salt diet on Th17 cells. Immunofluorescent staining with IL-17A showed abundant Th17 cells in the tarsal joints of CIA mice. IL-17-producing cells were identified more frequently in CIA mice fed a high-salt diet than control CIA mice (Fig. 4A). We examined the presence of IL$17^{+}$cells in the intestinal mucosa and submucosa by immunohistochemical and immunofluorescence staining because we were also interested in whether dietary $\mathrm{NaCl}$ would directly affect the immune cells in the intestinal tissue. IL- $17^{+}$cells were absent in the intestine of wild-type mice, whereas CIA mice fed a normal or high-salt diet both expressed IL-17, mainly in the small intestine (Fig. 4B). IL-17-producing cells were more abundant in the intestinal submucosa of high-saltfed CIA mice, compared with control CIA mice. Although IL$17^{+}$cell infiltration into the large intestine of CIA mice was not prominent, cellular aggregates stained with anti-IL-17 antibodies were found in the colonic submucosa of high-salt-fed CIA mice (Fig. 4C). Manual cell counting of IL- $17^{+}$cells in the synovium and gastrointestinal tract showed a significantly higher amount of IL- $17^{+}$cells in high-salt-fed CIA mice than in control CIA mice (Fig. 4D).

\section{NaCl-rich environment in synovial fluid from RA patients is associated with Th17 polarization}

Consistent with the results from animal experiments, human T cells isolated from patients with RA or OA showed enhanced Th17 differentiation at high $\mathrm{NaCl}$ concentrations (Fig. 5A). $\mathrm{NaCl}$ increased the expression of ROR $\gamma \mathrm{t}$ and IL-17, and had the greatest effect at a concentration of $40 \mathrm{mM}$. At a concentration of $60 \mathrm{mM} \mathrm{NaCl}$, T cells exhibited apoptosis, and the expression level of ROR $\gamma \mathrm{t}$ and IL-17 was reduced. To confirm the effect of $\mathrm{NaCl}$ on Th17 differentiation of human T cells, we recruited additional patients with $\mathrm{RA}(\mathrm{n}=3)$ and $\mathrm{OA}(\mathrm{n}=2)$ and collected $\mathrm{CD} 4^{+} \mathrm{T}$ cells from the peripheral blood of those patients. $\mathrm{CD} 4^{+} \mathrm{T}$ cells of individual patients were cultured under Th17 polarizing condition in the absence or the presence of $40 \mathrm{mM} \mathrm{NaCl}$. Flow cytometry showed that the expression of ROR $\gamma$ t and IL-17 consistently increased after $\mathrm{NaCl}$ treatment (Fig. 5B). The $\mathrm{CD}^{+} \mathrm{T}$ cell response in high $\mathrm{NaCl}$ concentrations showed similar patterns in RA and OA patients: 1.5- to 

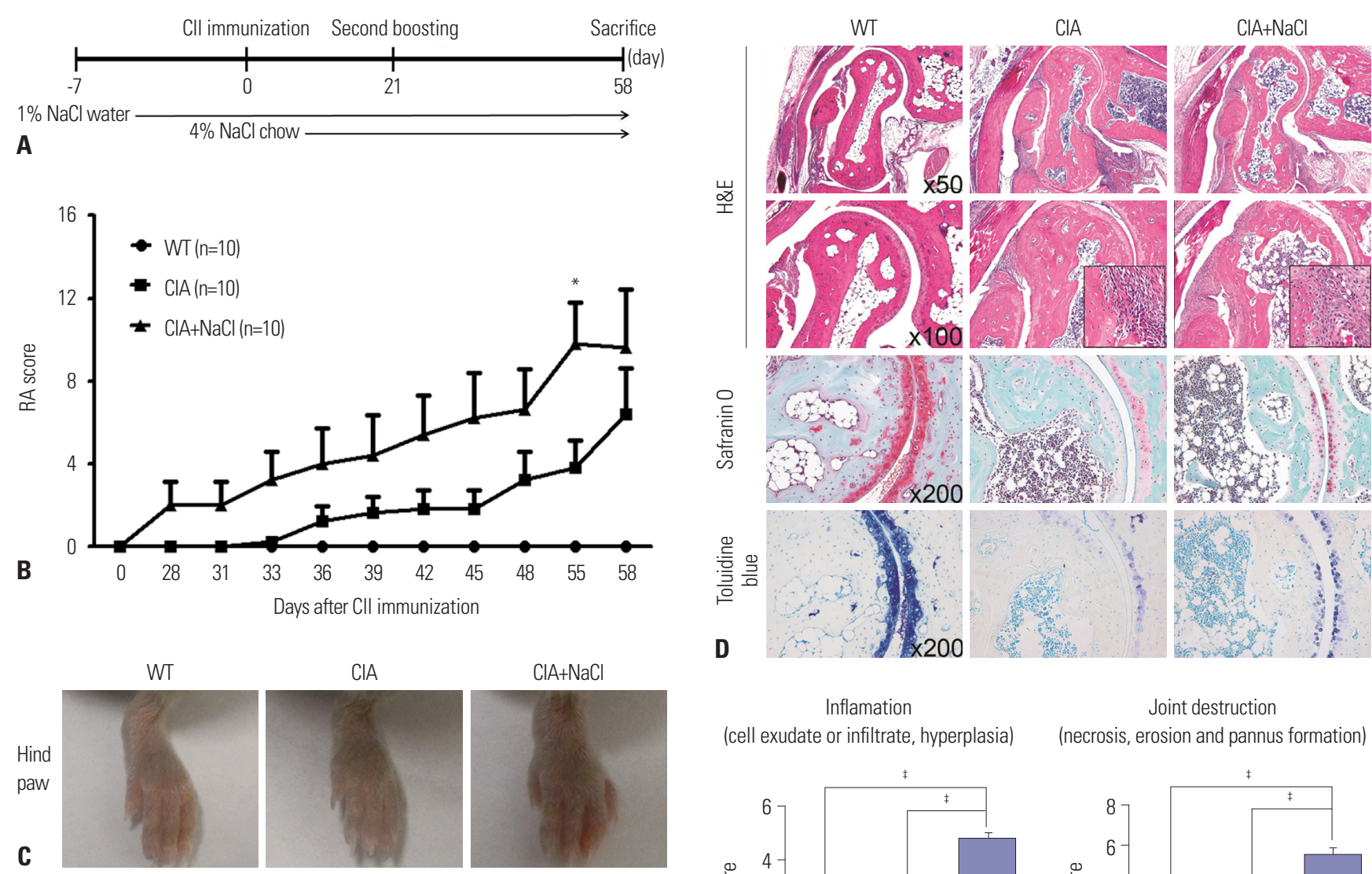

$\mathrm{ClA}+\mathrm{NaCl}$
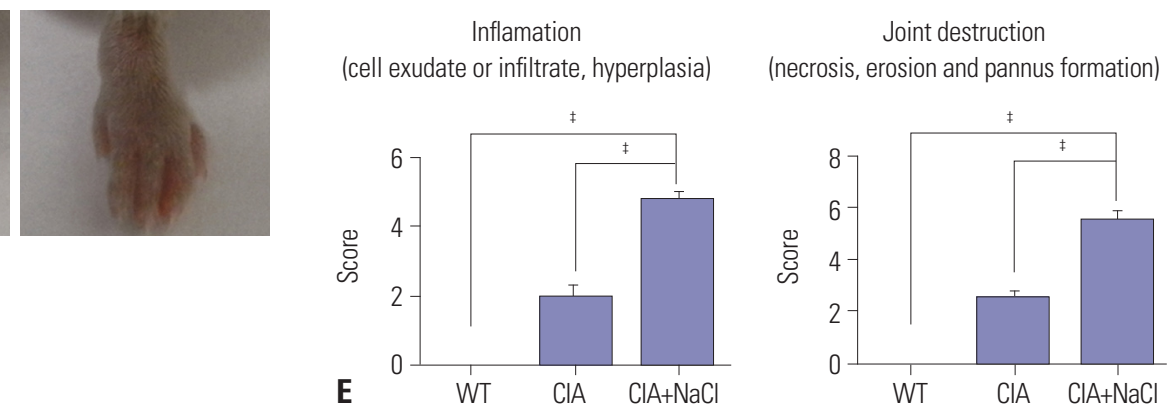

Fig. 2. High-salt diet aggravates inflammatory arthritis in CIA mice. (A) Time schedule for salt ingestion in CIA mice. Salt-containing water and chow were started 1 week before and at the time of CII immunization, respectively. (B) Mean arthritis scores in wild-type mice (WT), CIA mice (CIA), and CIA mice fed a high-salt diet (CIA+NaCl). Arthritis of each paw was scored from 0 (no swelling) to 4 (erythema and severe swelling encompassing the ankle and foot). The arthritis score is the sum of the scores for the four paws. Data represent the mean arthritis score $\pm S E M .{ }^{*} p<0.05$. (C) Representative photographs of hind paws in control mice and CIA mice fed a high-salt diet. The hind paws of WT, CIA, and CIA+NaCl showed a different degree of swelling at day 58 after primary Cll immunization. (D) Histological analysis of tarsal joints in control mice and CIA mice fed a high-salt diet. The tissue sections obtained at 58 days were stained with hematoxylin and eosin (H\&E), Safranin 0 , and toluidine blue. The magnifications are indicated in the right bottom corner. (E) The mean histological score of the tarsal joints in each group. Inflammation and joint destruction were scored on a scale of 0-3 by three independent examiners. The data represent the mean histological score \pm SEM. ${ }^{\ddagger} p<0.001$.

\section{0-fold increases in Th17 differentiation.}

Because RA is characterized by inflammatory synovitis, white blood cell counts in synovial fluid from RA patients was markedly higher than in that from OA patients (median value of 16000 cells $/ \mathrm{mm}^{3}$ vs. 95.5 cells $/ \mathrm{mm}^{3}, p<0.0001$ ) (Fig. 5C). The concentration of IL-17 was also significantly higher in RA synovial fluid than in OA synovial fluid ( $p=0.008$ ). Interestingly, the $\mathrm{Na}^{+}$concentration was much higher in RA synovial fluid than in OA synovial fluid (median value of $135 \mathrm{mEq} / \mathrm{L}$ vs. $68 \mathrm{mEq} / \mathrm{L}$, $p<0.0001)$.

\section{DISCUSSION}

The present study showed that $\mathrm{NaCl}$ aggravates inflammatory arthritis in CIA mice through Th17 cell induction. Mice fed a high-salt diet showed a higher proportion of Th17 cells in the spleen and joints, compared to control CIA mice, and $\mathrm{CD} 4^{+} \mathrm{T}$ cells from high-salt-fed CIA mice were likely to differentiate into Th17 cells. High-salt diet also increased the proportion of IL-17-producing cells in the synovium and intestine of CIA mice. The synovial fluid of RA patients contained larger amounts of sodium and IL-17, suggesting an association between $\mathrm{NaCl}$ and $\mathrm{Th} 17$ cells.

Consistent with a recent report, ${ }^{8}$ we found an in vitro effect of $\mathrm{NaCl}$ on $\mathrm{Th} 17$ differentiation in a dose-dependent manner. The most potent $\mathrm{NaCl}$ concentration for Th17 development was $40 \mathrm{mM}$ in the culture media. Interestingly, several previous studies also showed that the $\mathrm{NaCl}$ concentration of 40 $\mathrm{mM}$ had the greatest effect in modulating immune cells and that the experimental cell lines lost their viability at concentrations above $40 \mathrm{mM}$ of $\mathrm{NaCl}^{8,18,19}$ Although the tolerable 

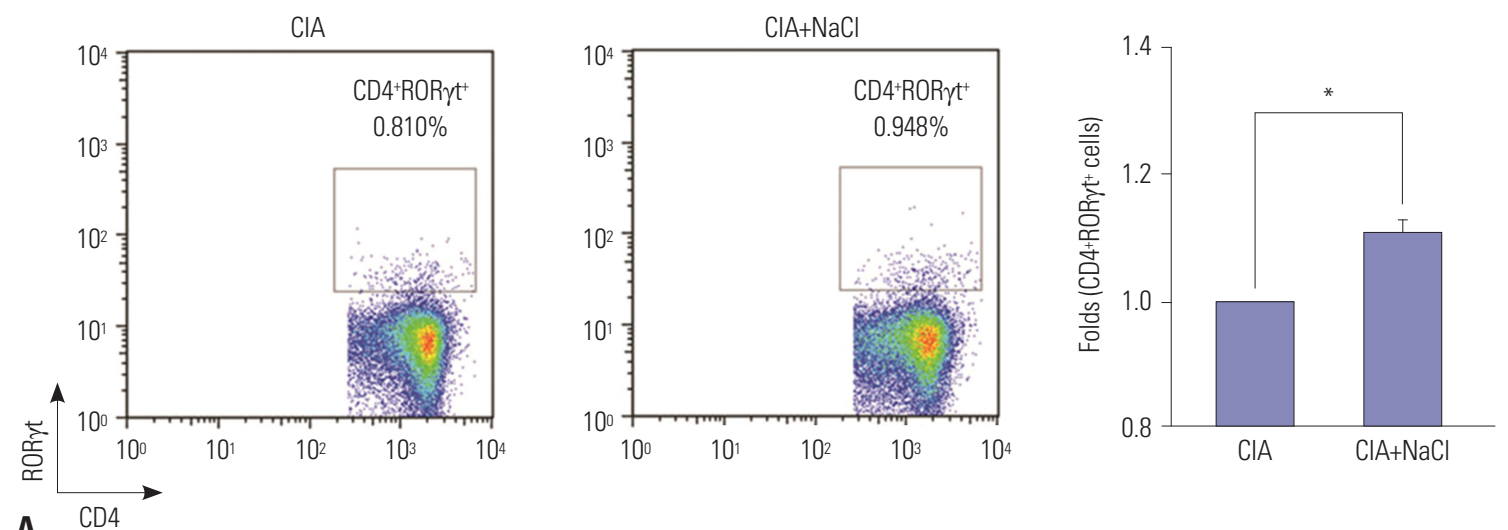

A $\mathrm{CD} 4$

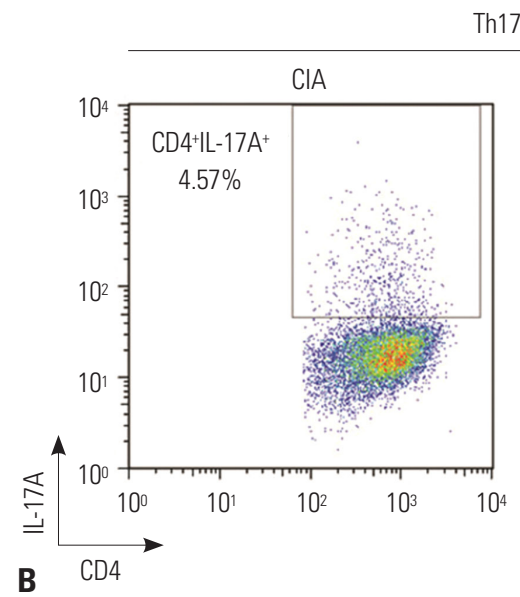

177 polarization
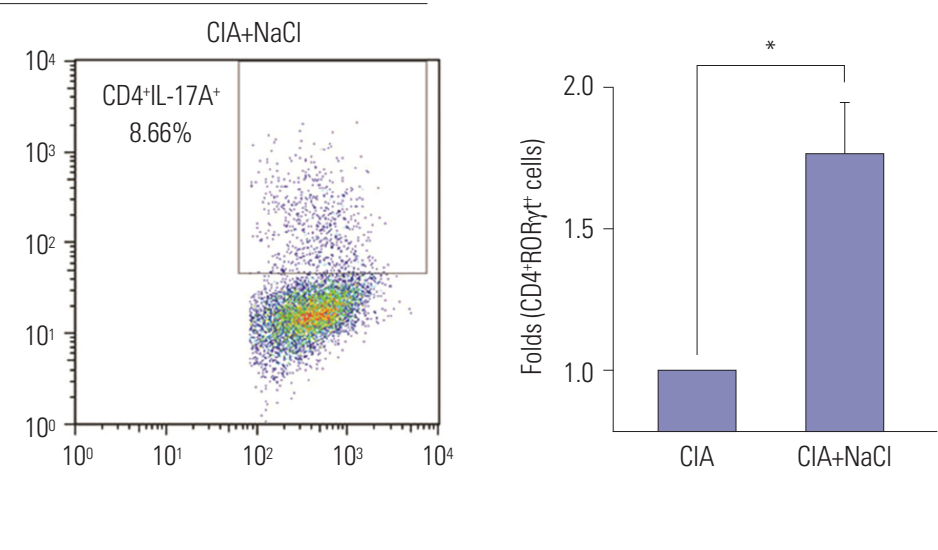

Fig. 3. NaCl-rich condition primes Th17 polarization in mice with CIA. (A) Flow cytometry analysis of naïve $\mathrm{CD}^{+} \mathrm{T}$ cells in spleens isolated from control CIA mice (CIA) and high-salt-fed CIA mice (CIA+NaCl). Representative plots of Th17 population among naïve $\mathrm{CD}^{+}{ }^{\top} \mathrm{T}$ cells in both groups are presented, and fold increases were calculated as the percentage of $\mathrm{CD} 4^{+} \mathrm{ROR} \gamma \mathrm{t}^{+} \mathrm{Th} 17$ cells relative to the percentage in control $\mathrm{CIA}$ mice. (B) Flow cytometry analysis of naïve $\mathrm{CD}^{+} \mathrm{T}$ cells isolated from $\mathrm{CIA}$ and $\mathrm{CIA}+\mathrm{NaCl}$ mice cultured under Th17-polarizing conditions. Splenocytes were isolated from CIA mice fed a normal or a high-salt diet to evaluate the priming effect of $\mathrm{NaCl}$ on Th17 differentiation. Purified naïve $\mathrm{CD}^{+} \mathrm{T}$ cells were cultured under Th17 differentiating condition for 3 days. Representative plots of differentiated CD4 ${ }^{+} I L-17 A^{+} T h 17$ cells from naïve CD4 ${ }^{+} T$ cells isolated from both groups were presented, and fold increases were calculated as the percentage of $\mathrm{CD} 4^{+} \mathrm{IL}-17 \mathrm{~A}^{+} \mathrm{Th} 17$ cells relative to the percentage in the control CIA group. Data are representative of three independent experiments and are expressed as mean \pm SEM. ${ }^{*} p<0.05$.

concentration of $\mathrm{NaCl}$ in the culture condition is not clear, the threshold might be less than $60 \mathrm{mM}$ of $\mathrm{NaCl}$. There is one study showing the effect of high-salt diet on sodium concentration in vivo. Machnik, et al. ${ }^{18}$ reported that the skin $\mathrm{Na}^{+}$contents in rats fed a high-salt diet and a low-salt diet were about $200 \mathrm{mM}$ and $150 \mathrm{mM}$, respectively. There was no significant difference in serum $\mathrm{Na}+$ level between two groups. This finding suggests that $\mathrm{NaCl}$ accumulates in the interstitium without a change in serum $\mathrm{Na}^{+}$concentration. After high-salt intake, the regulatory mechanisms maintained the interstitial sodium concentration within $50 \mathrm{mM}$-difference to keep the physiological state of the body.

We also investigated the distribution of IL-17-producing cells in the gastrointestinal tract based on the assumption that the NaCl-rich dietary content would induce Th17 differentiation of the mucosal immune system. Similar to the in vitro experiments, the high-salt diet promoted intestinal IL-17 production in CIA mice. IL-17 is primarily secreted from Th17 cells, although there are a few cell populations that express IL-17 in the intestine. ${ }^{20}$ Therefore, the presence of IL-17 in the intestinal tract of CIA mice fed a high-salt diet may indicate that the salt component promotes Th17 differentiation in the intestines.

The gut is the largest organ in the immune system and is responsible for the maintenance of homeostasis between host immunity and diverse antigenic stimuli, including food and commensal microorganisms. Previous research has shown that the gut microbiota is associated with Th17 differentiation in the intestinal tissues. ${ }^{21,22}$ In this study, we did not examine changes in intestinal microflora after salt ingestion. It is unclear whether high $\mathrm{NaCl}$ concentration in the intestinal lumen directly induces Th17 polarization or whether salt-containing foods alter the intestinal flora and then influence $\mathrm{T}$ cell differentiation. $\mathrm{Al}$ though the precise mechanism for intestinal Th17 differentiation after salt intake is difficult to define, the induction of intestinal Th17 cells by $\mathrm{NaCl}$ could be responsible for exacerbation of the autoimmune arthritis. There is evidence that suggests a significant association between intestinal Th17 cells and extraintestinal autoimmunity. Germ-free animals with fewer intesti- 

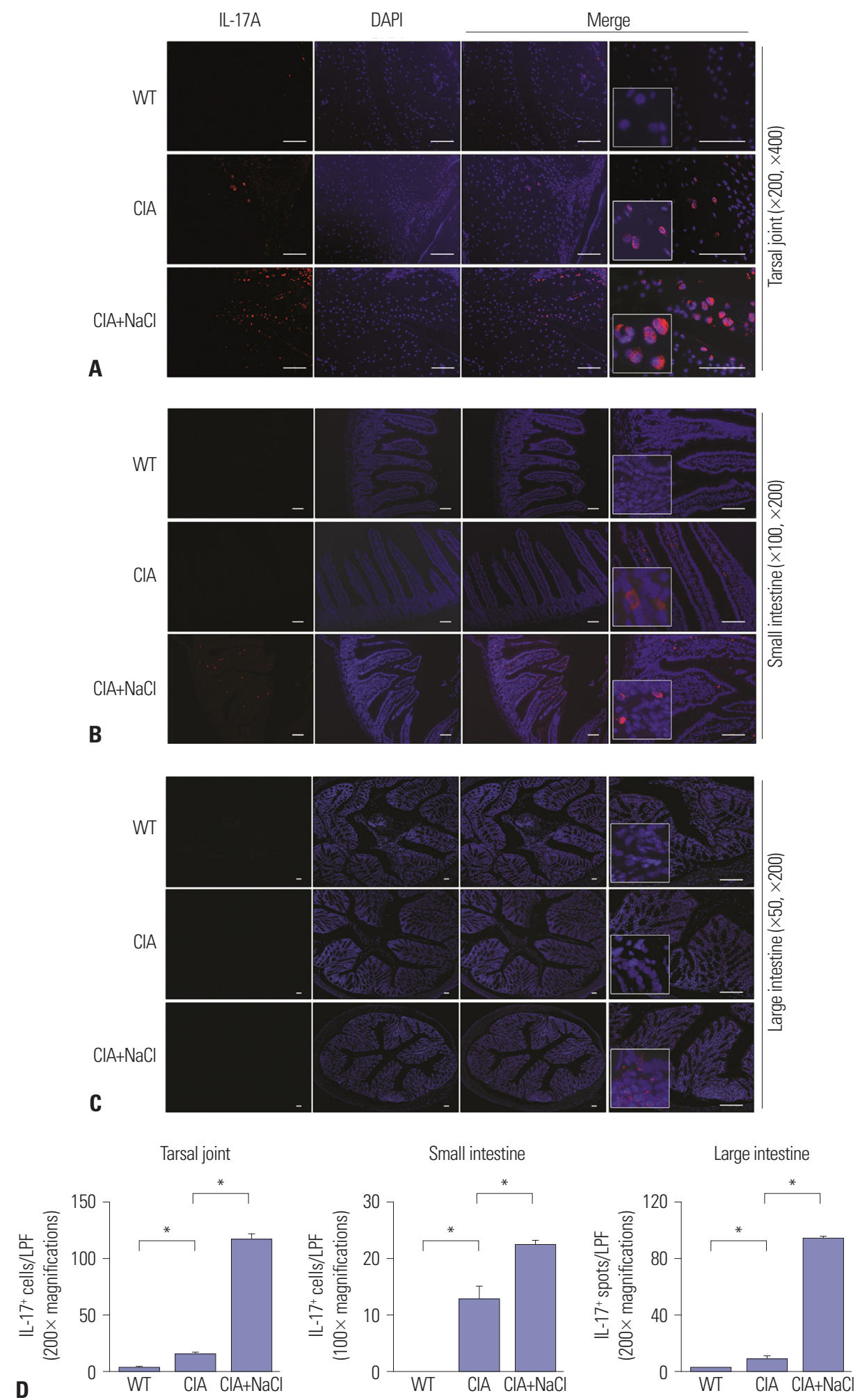

Fig. 4. Salt intake increases IL-17 expression in the synovium and gut of CIA mice. (A-C) Expression of IL-17A in the joint synovium, small intestine, and large intestine in WT mice and CIA mice fed a normal diet (CIA) or a high-salt diet (CIA+NaCI). Immunohistochemical staining with anti-IL-17A antibodies was performed in tissue sections of joint (A), small intestine (B), and large intestine (C) obtained from experimental animals on day 58 . Representative images in each group are shown, and the area with cellular deposition was enlarged. The magnification is presented in the right bottom corner, and scale bars indicate $100 \mu \mathrm{m}$. (D) Quantification of IL-17 cells in the joint and small intestine and IL-17 $7^{+}$spots in the large intestine observed in a low power field (LPF) $\left(\times 100\right.$ or $\times 200$ as presented in the graphs). The number of IL- $17^{+}$cells or spots was determined by three independent examiners. The data are expressed as mean \pm SEM. ${ }^{*} p<0.05$. 
Patients with RA

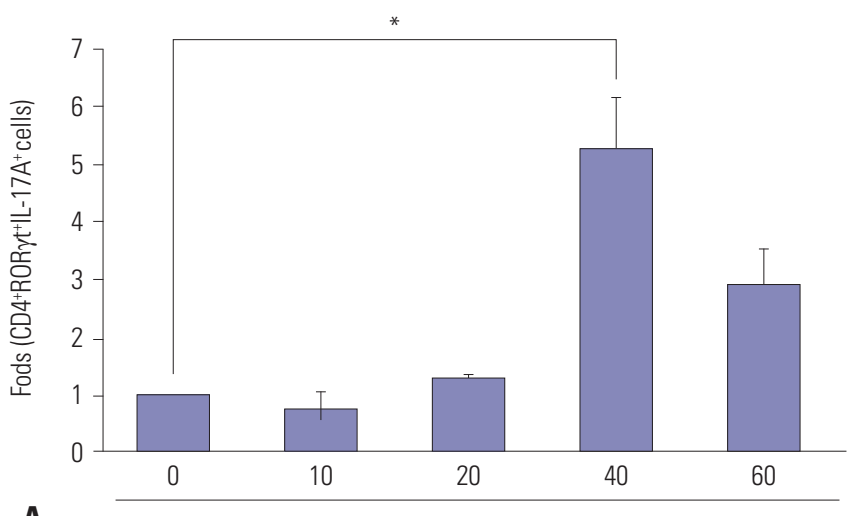

A

$+\mathrm{NaCl}$ concentrations (mM)
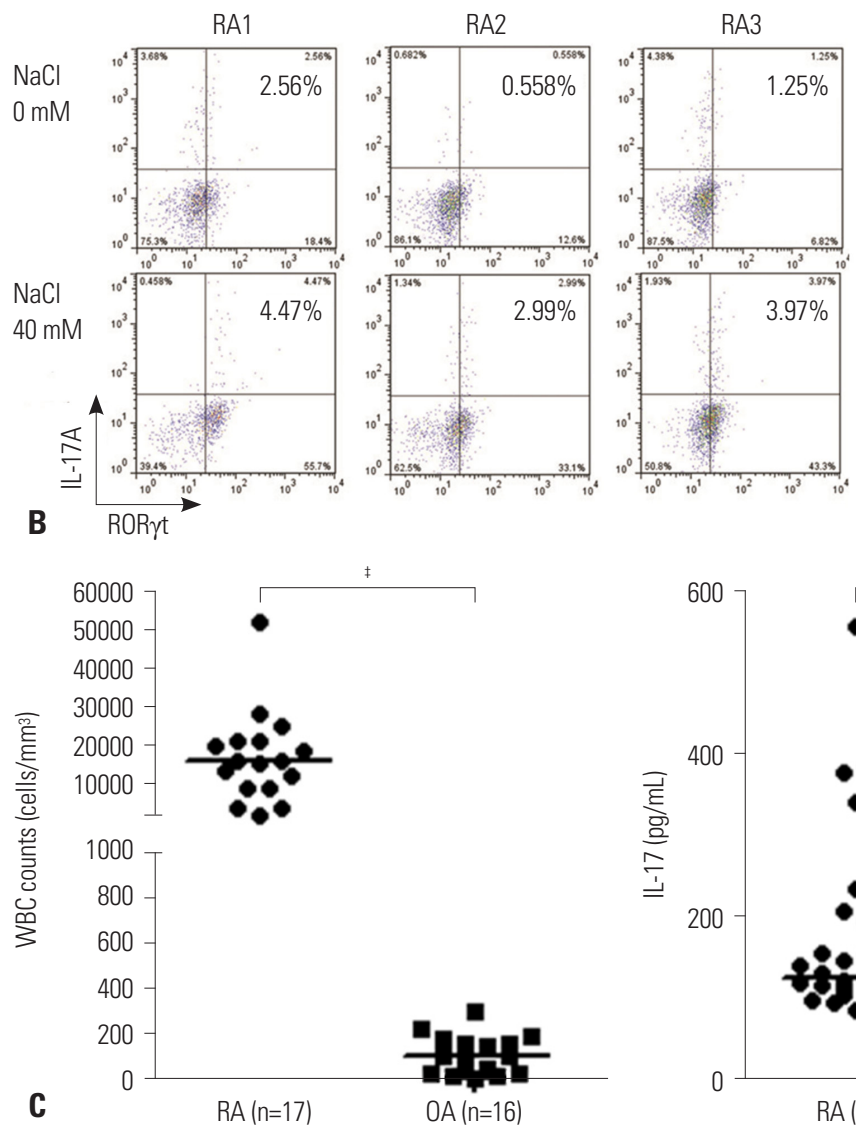

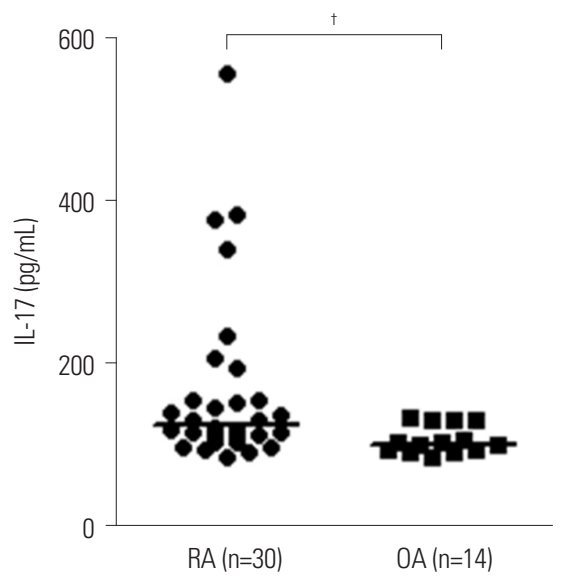

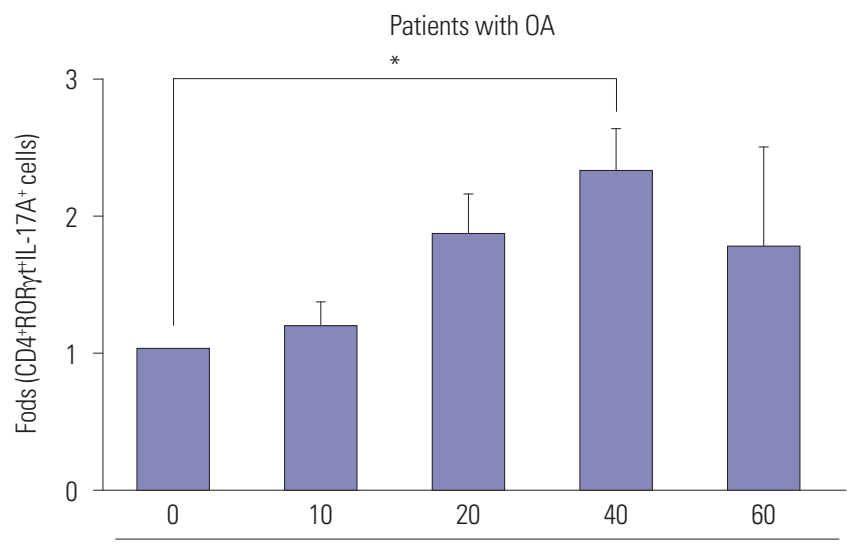

$+\mathrm{NaCl}$ concentrations (mM)
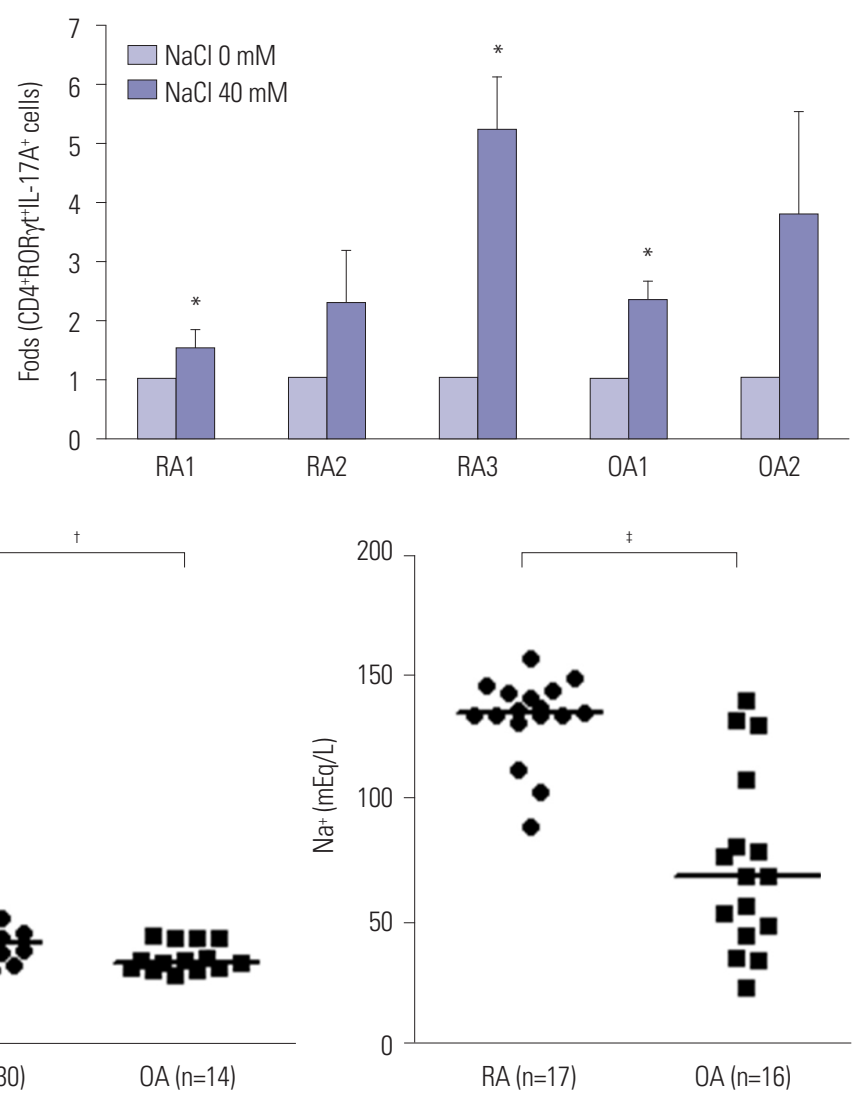

Fig. 5. Synovial fluid from RA patients contained higher levels of sodium and IL-17 compared with those from OA patients. (A) Changes in Th17 differentiation from human $\mathrm{CD}^{+} \mathrm{T}$ cells after treatment with various doses of $\mathrm{NaCl}$. Naïve $\mathrm{CD} 4^{+} \mathrm{T}$ cells from peripheral blood were cultured under Th17-polarizing conditions with or without $\mathrm{NaCl}$ at different concentrations $(10,20,40$, and $60 \mathrm{mM})$ for 3 days. RORyt $\mathrm{tL}-17 \mathrm{~A}^{+}$Th17 cells were detected by flow cytometry. Fold differences at the different concentrations were expressed relative to the $\mathrm{NaCl}$-deficient condition. (B) The effect of $\mathrm{NaCl}$ on Th17 differentiation in human cells obtained from RA and OA patients. Representative flow cytometry plots for Th17 differentiation at $\mathrm{NaCl} 0 \mathrm{mM}$ and $40 \mathrm{mM}$ are shown in patients with $\mathrm{RA}(\mathrm{n}=3)$ and $\mathrm{OA}(\mathrm{n}=2)$. Fold increases in differentiated Th17 cells were expressed relative to the NaCl-deficient condition. The graph represents the data from individual patients. Data represent the mean of three independent experiments \pm SEM. ${ }^{*} p<0.05$. (C) Characteristics of synovial fluid obtained from RA patients and OA patients. Leukocyte count and sodium concentration in synovial fluid were measured by routine laboratory methods. IL-17 level in the synovial fluid was determined by ELISA. Horizontal bars for analysis of synovial fluid indicate the median of all values in a group. ${ }^{\dagger} p<0.01$, ${ }^{\ddagger} p<0.001$. RA, rheumatoid arthritis; OA, osteoarthritis; WBC, white blood cell.

nal Th17 cells are resistant to the development of autoimmune arthritis and experimental autoimmune encephalomyelitis. ${ }^{23,24}$

Interestingly, the synovial $\mathrm{Na}^{+}$concentration was significantly higher in patients with RA than in those with OA. The mean $\mathrm{Na}^{+}$concentration in RA synovial fluid was $135 \mathrm{mEq} / \mathrm{L}$, similar to the in vitro $\mathrm{NaCl}$ concentration when $40 \mathrm{mM} \mathrm{NaCl}$ was added to the culture media (104.4 mM). The highest $\mathrm{Na}^{+}$ concentration in RA synovial fluid was $157 \mathrm{mEq} / \mathrm{L}$. In consid- 
eration of the in vitro result that T cells exhibited apoptosis at concentrations above $60 \mathrm{mM} \mathrm{NaCl}(\geq 164.4 \mathrm{mM}$ in the culture media), the synovial $\mathrm{Na}^{+}$concentration above $160 \mathrm{mEq} / \mathrm{L}$ may be a difficult condition for lymphocyte proliferation and inflammatory activation. To the best of our knowledge, this is the first report showing the $\mathrm{Na}^{+}$concentration in $\mathrm{RA}$ synovial fluid. Further investigation would be required to elucidate the association between synovial $\mathrm{Na}^{+}$concentration and inflammatory responses.

In this study, the inflammatory response of $\mathrm{CD}^{+} \mathrm{T}$ cells to high $\mathrm{NaCl}$ concentrations was not significantly different between RA patients and OA patients. However, hypernatremic synovial fluid from RA patients can provide a milieu favoring Th17 polarization. In addition to Th17 differentiation, hypertonicity is essential for lymphocyte proliferation and maturation. Physiologically, lymphoid tissue is hyperosmolar compared with serum. ${ }^{25}$ Hypertonic saline promotes T cell proliferation ${ }^{26}$ by activating the signaling pathway in $\mathrm{T}$ cells ${ }^{27}$ and reversing prostaglandin E-mediated T cell suppression. ${ }^{28}$ Thus, hypernatremic hypertonicity in RA synovial fluid may increase Th17 differentiation and lymphocyte proliferation, leading to exacerbation of the inflammatory environment.

Similar to previous studies, we found that a NaCl-rich environment enhances the expression of $\mathrm{ROR} \gamma \mathrm{t}$, which is a critical transcription factor for Th17 differentiation. ${ }^{1}$ Induction of ROR $\gamma \mathrm{t}$ in high-salt condition was consistently represented by in vitro and in vivo experiments. High-salt diet exacerbated the severity of experimental autoimmune encephalomyelitis and experimental colitis, and expression of ROR $\gamma \mathrm{t}$ was more prominent in mice fed a high-salt diet, compared to control mice. $^{8,29}$ Microarray analysis also showed the increased expression of $R O R C$ in T cells under high-salt conditions. ${ }^{8,9,30}$ Considering the loss of sodium-induced increase of Th17 signatures, including ROR $\gamma \mathrm{t}$, in SGK1-deficient T cells, ${ }^{9,31}$ SGK1 can be a link between salt and ROR $\gamma$ t. However, it is difficult to conclude that the worsening of inflammatory arthritis by sodium intake is entirely due to Th17 polarization. Earlier studies have suggested a significant association between immunity and hypertonicity. Autoimmunity can be regulated by inhibition of angiotensin-converting enzyme, ${ }^{32}$ which is activated by hypertonicity due to salt ingestion. ${ }^{33}$ This inhibitory effect is mediated by inducing regulatory $\mathrm{T}$ cells and by modulating Th1 and Th17 responses. ${ }^{32}$ Hypertonic saline also stimulates innate immunity in vivo by up-regulating the expression of Toll-like receptor signaling. ${ }^{34,35}$ In addition, salt intake is associated with an increase in inflammatory cytokines. In animal models of gastric carcinogenesis, a high-salt diet increases the production of pro-inflammatory cytokines, including IL-1, IL-6, and TNF- $\alpha \cdot{ }^{36,37}$ In healthy adolescents, average sodium intake correlates with serum levels of TNF- $\alpha$, independently of adipose tissues. ${ }^{38}$ Therefore, in addition to Th17 differentiation, various inflammatory responses may contribute to exacerbation of arthritis.
In clinical studies, an association between high-salt diet and autoimmune disease remains unclear. A recent study suggests that a high salt diet may be associated with increased disease activity in patients with multiple sclerosis. ${ }^{39}$ In Chinese patients with systemic lupus erythematosus, excessive salt intake was associated with treatment failure despite intensive glucocorticoid treatment. ${ }^{40}$ Additional epidemiologic studies and intervention studies that limit salt intake are required to clarify the causal relationship between salt intake and autoimmune diseases.

In conclusion, $\mathrm{NaCl}$ can aggravate arthritis by stimulating Th17 differentiation. To our knowledge, this is the first report to demonstrate a proarthritic effect of salt in an animal model. A low-salt dietary approach to alleviate the symptoms and signs of inflammatory arthritis has not yet been studied. Although diet plays an auxiliary role in primary treatment based on immunosuppressants, dietary modifications can be applied as a treatment approach for RA because there are no side effects and costs are minimal.

\section{ACKNOWLEDGEMENTS}

This work was supported by a grant from the Korea Healthcare Technology R\&D Project, Ministry for Health, Welfare \& Family Affairs, Republic of Korea (A092258); the Basic Science Research Program through the National Research Foundation of Korea (NRF), funded by the Ministry of Science, ICT, \& Future Planning (2013R1A1A1076125); and a grant from "The Center for Evaluating Next-Generation Stem Cell-based Therapeutics," supported by the National Institute of Food and Drug Safety Evaluation, part of the Ministry of Drug and Food Safety (14172 CENST 974).

\section{ORCID iDs}

Seung Min Jung Youngkyun Kim Juryun Kim Hyerin Jung Hyoju Yi Yeri Alice Rim Narae Park Seung-Ki Kwok Sung-Hwan Park Ji Hyeon Ju https://orcid.org/0000-0003-3465-2181
https://orcid.org/0000-0003-3078-6852
https://orcid.org/0000-0001-9571-1734
https://orcid.org/0000-0002-1231-8660
https://orcid.org/0000-0002-6786-4327
https://orcid.org/0000-0001-9541-3075
https://orcid.org/0000-0002-4859-1351
https://orcid.org/0000-0002-6142-8364
https://orcid.org/0000-0003-1711-2060
https://orcid.org/0000-0002-1381-5466

\section{REFERENCES}

1. Miossec P, Korn T, Kuchroo VK. Interleukin-17 and type 17 helper T cells. N Engl J Med 2009;361:888-98.

2. McInnes IB, Schett G. The pathogenesis of rheumatoid arthritis. N Engl J Med 2011;365:2205-19.

3. Proudman SM, James MJ, Spargo LD, Metcalf RG, Sullivan TR, Rischmueller M, et al. Fish oil in recent onset rheumatoid arthritis: a randomised, double-blind controlled trial within algorithmbased drug use. Ann Rheum Dis 2015;74:89-95. 
4. Park Y, Lee A, Shim SC, Lee JH, Choe JY, Ahn H, et al. Effect of n-3 polyunsaturated fatty acid supplementation in patients with rheumatoid arthritis: a 16-week randomized, double-blind, placebo-controlled, parallel-design multicenter study in Korea. J Nutr Biochem 2013;24:1367-72.

5. Salesi M, Farajzadegan Z. Efficacy of vitamin D in patients with active rheumatoid arthritis receiving methotrexate therapy. Rheumatol Int 2012;32:2129-33.

6. McKellar G, Morrison E, McEntegart A, Hampson R, Tierney A, Mackle G, et al. A pilot study of a Mediterranean-type diet intervention in female patients with rheumatoid arthritis living in areas of social deprivation in Glasgow. Ann Rheum Dis 2007;66: 1239-43.

7. Lahiri M, Morgan C, Symmons DP, Bruce IN. Modifiable risk factors for RA: prevention, better than cure? Rheumatology (Oxford) 2012;51:499-512.

8. Kleinewietfeld M, Manzel A, Titze J, Kvakan H, Yosef N, Linker RA, et al. Sodium chloride drives autoimmune disease by the induction of pathogenic TH17 cells. Nature 2013;496:518-22.

9. Wu C, Yosef N, Thalhamer T, Zhu C, Xiao S, Kishi Y, et al. Induction of pathogenic TH17 cells by inducible salt-sensing kinase SGK1. Nature 2013;496:513-7.

10. Meng F, Yamagiwa Y, Taffetani S, Han J, Patel T. IL-6 activates serum and glucocorticoid kinase via p38alpha mitogen-activated protein kinase pathway. Am J Physiol Cell Physiol 2005;289:C971-81.

11. Masuda K, Masuda R, Neidhart M, Simmen BR, Michel BA, Müller-Ladner $\mathrm{U}$, et al. Molecular profile of synovial fibroblasts in rheumatoid arthritis depends on the stage of proliferation. Arthritis Res 2002;4:R8.

12. Yoon HJ, You S, Yoo SA, Kim NH, Kwon HM, Yoon CH, et al. NFAT5 is a critical regulator of inflammatory arthritis. Arthritis Rheum 2011;63:1843-52.

13. Brand DD, Latham KA, Rosloniec EF. Collagen-induced arthritis. Nat Protoc 2007;2:1269-75.

14. Arnett FC, Edworthy SM, Bloch DA, McShane DJ, Fries JF, Cooper NS, et al. The American Rheumatism Association 1987 revised criteria for the classification of rheumatoid arthritis. Arthritis Rheum 1988;31:315-24.

15. Aletaha D, Neogi T, Silman AJ, Funovits J, Felson DT, Bingham CO 3rd, et al. 2010 rheumatoid arthritis classification criteria: an American College of Rheumatology/European League Against Rheumatism collaborative initiative. Ann Rheum Dis 2010;69: 1580-8.

16. Altman R, Asch E, Bloch D, Bole G, Borenstein D, Brandt K, et al. Development of criteria for the classification and reporting of osteoarthritis. Classification of osteoarthritis of the knee. Diagnostic and Therapeutic Criteria Committee of the American Rheumatism Association. Arthritis Rheum 1986;29:1039-49.

17. Hückel M, Schurigt U, Wagner AH, Stöckigt R, Petrow PK, Thoss K, et al. Attenuation of murine antigen-induced arthritis by treatment with a decoy oligodeoxynucleotide inhibiting signal transducer and activator of transcription-1 (STAT-1). Arthritis Res Ther 2006;8:R17.

18. Machnik A, Neuhofer W, Jantsch J, Dahlmann A, Tammela T, Machura K, et al. Macrophages regulate salt-dependent volume and blood pressure by a vascular endothelial growth factor-C-dependent buffering mechanism. Nat Med 2009;15:545-52.

19. Müller S, Quast T, Schröder A, Hucke S, Klotz L, Jantsch J, et al. Salt-dependent chemotaxis of macrophages. PLoS One 2013;8: e73439.

20. Garrido-Mesa N, Algieri F, Rodríguez Nogales A, Gálvez J. Functional plasticity of Th17 cells: implications in gastrointestinal tract function. Int Rev Immunol 2013;32:493-510.

21. Kamada N, Núñez G. Role of the gut microbiota in the develop- ment and function of lymphoid cells. J Immunol 2013;190:1389-95.

22. Sommer F, Bäckhed F. The gut microbiota--masters of host development and physiology. Nat Rev Microbiol 2013;11:227-38.

23. Wu HJ, Ivanov II, Darce J, Hattori K, Shima T, Umesaki Y, et al. Gut-residing segmented filamentous bacteria drive autoimmune arthritis via T helper 17 cells. Immunity 2010;32:815-27.

24. Lee YK, Menezes JS, Umesaki Y, Mazmanian SK. Proinflammatory T-cell responses to gut microbiota promote experimental autoimmune encephalomyelitis. Proc Natl Acad Sci U S A 2011;108 Suppl 1: 4615-22.

25. Go WY, Liu X, Roti MA, Liu F, Ho SN. NFAT5/TonEBP mutant mice define osmotic stress as a critical feature of the lymphoid microenvironment. Proc Natl Acad Sci U S A 2004;101:10673-8.

26. Junger WG, Liu FC, Loomis WH, Hoyt DB. Hypertonic saline enhances cellular immune function. Circ Shock 1994;42:190-6.

27. Junger WG, Hoyt DB, Hamreus M, Liu FC, Herdon-Remelius C, Junger W, et al. Hypertonic saline activates protein tyrosine kinases and mitogen-activated protein kinase p38 in T-cells. J Trauma 1997;42:437-43.

28. Coimbra R, Junger WG, Liu FC, Loomis WH, Hoyt DB. Hypertonic/hyperoncotic fluids reverse prostaglandin E2 (PGE2)-induced T-cell suppression. Shock 1995;4:45-9.

29. Monteleone I, Marafini I, Dinallo V, Di Fusco D, Troncone E, Zorzi F, et al. Sodium chloride-enriched diet enhanced inflammatory cytokine production and exacerbated experimental colitis in mice. J Crohns Colitis 2017;11:237-45.

30. Hernandez AL, Kitz A, Wu C, Lowther DE, Rodriguez DM, Vudattu N, et al. Sodium chloride inhibits the suppressive function of FOXP3+ regulatory T cells. J Clin Invest 2015;125:4212-22.

31. Wu C, Chen Z, Xiao S, Thalhamer T, Madi A, Han T, et al. SGK1 governs the reciprocal development of Th17 and regulatory $\mathrm{T}$ cells. Cell Rep 2018;22:653-65.

32. Platten M, Youssef S, Hur EM, Ho PP, Han MH, Lanz TV, et al. Blocking angiotensin-converting enzyme induces potent regulatory T cells and modulates TH1- and TH17-mediated autoimmunity. Proc Natl Acad Sci U S A 2009;106:14948-53.

33. Crestani S, Gasparotto Júnior A, Marques MC, Sullivan JC, Webb RC, da Silva-Santos JE. Enhanced angiotensin-converting enzyme activity and systemic reactivity to angiotensin II in normotensive rats exposed to a high-sodium diet. Vascul Pharmacol 2014;60:67-74.

34. Chen LW, Huang HL, Lee IT, Hsu CM, Lu PJ. Hypertonic saline enhances host defense to bacterial challenge by augmenting Tolllike receptors. Crit Care Med 2006;34:1758-68.

35. Chen LW, Su MT, Chen PH, Liu WC, Hsu CM. Hypertonic saline enhances host defense and reduces apoptosis in burn mice by increasing toll-like receptors. Shock 2011;35:59-66.

36. Gaddy JA, Radin JN, Loh JT, Zhang F, Washington MK, Peek RM Jr, et al. High dietary salt intake exacerbates Helicobacter pyloriinduced gastric carcinogenesis. Infect Immun 2013;81:2258-67.

37. Leung WK, Wu KC, Wong CY, Cheng AS, Ching AK, Chan AW, et al. Transgenic cyclooxygenase-2 expression and high salt enhanced susceptibility to chemical-induced gastric cancer development in mice. Carcinogenesis 2008;29:1648-54.

38. Zhu H, Pollock NK, Kotak I, Gutin B, Wang X, Bhagatwala J, et al. Dietary sodium, adiposity, and inflammation in healthy adolescents. Pediatrics 2014;133:e635-42.

39. Farez MF, Fiol MP, Gaitán MI, Quintana FJ, Correale J. Sodium intake is associated with increased disease activity in multiple sclerosis. J Neurol Neurosurg Psychiatry 2015;86:26-31.

40. Zou YF, Xu JH, Tao JH, Xu SQ, Liu S, Chen SY, et al. Impact of environmental factors on efficacy of glucocorticoids in Chinese population with systemic lupus erythematosus. Inflammation 2013;36: 1424-30. 